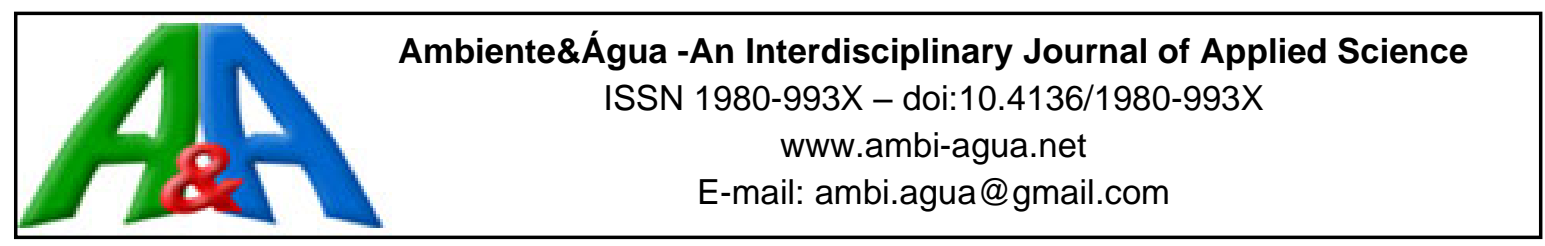

\title{
Biomass burning and cardiovascular diseases in Mato Grosso State: a spatial approach
}

\author{
doi:10.4136/ambi-agua.2312
}

Received:16 Nov. 2019; Accepted: 18 Dec. 2019

\section{Antônio Carlos Pereira dos Santos Junior ${ }^{1}$; Luiz Fernando Costa Nascimento ${ }^{2 *}$; Ana Aparecida da Silva Almeida ${ }^{3}$; Marcelo dos Santos Targa ${ }^{1}$}

\author{
${ }^{1}$ Departamento de Ciências Agrárias. Universidade de Taubaté (UNITAU), Est. Mun. Dr. José Luiz Cembranelli, \\ $\mathrm{n}^{\circ}$ 5000, CEP: 12081-010, Taubaté, SP, Brazil. \\ E-mail: antoniolinkon@gmail.com, targa.marcelo@gmail.com \\ ${ }^{2}$ Departamento de Medicina. Universidade de Taubaté (UNITAU), Av. Tiradentes, $\mathrm{n}^{\circ}$ 500, CEP: 12030-180, \\ Taubaté, SP, Brazil \\ ${ }^{3}$ Instituto Básico de Biociências (IBB). Universidade de Taubaté (UNITAU), Av. Tiradentes, $n^{\circ}$ 500, \\ CEP: 12030-180, Taubaté, SP, Brazil. E-mail: anaparecida.almeida@gmail.com \\ *Corresponding author. E-mail: luiz.nascimento@unitau.com.br
}

\begin{abstract}
Environmental factors have influenced human health leading to illness due to cardiovascular diseases. This ecological and exploratory study analyzes the spatial distribution of burn outbreaks and rates of hospitalizations due to cardiovascular diseases in the municipalities of the State of Mato Grosso between the years of 2012 and 2015. Thematic and kernel maps were created for the outbreaks of fires and for hospitalizations for the years 2012 to 2015. Moran Global indices, were calculated for these variables. During the study period, 758023 outbreaks of fires and 57269 hospitalizations were identified; Moran index were significant for burn outbreaks, but for hospitalization rates, except for 2012, there was no significant spatial autocorrelation. Thematic and kernel maps show higher occurrences of fires in the north of the state, in the so-called arch of deforestation, and higher hospitalization rates in the southern region of the state, possibly due to the action of winds, displacing pollutants generated by the fires to the south of the state.
\end{abstract}

Keywords: air pollutants, deforestation, environmental sciences, hospitalization rates.

\section{Queima de biomassa e doenças cardiovasculares no Mato Grosso: uma abordagem espacial}

\section{RESUMO}

Fatores ambientais influenciaram a saúde humana, levando a doenças cardiovasculares. Este estudo ecológico e exploratório analisa a distribuição espacial dos focos de incêndio e as taxas de hospitalizações por doenças cardiovasculares nos municípios do Estado de Mato Grosso entre os anos de 2012 e 2015. Foram criados mapas temáticos e de núcleo para os focos de incêndios e para internações hospitalares para os anos de 2012 a 2015. Os índices Moran Global foram calculados para essas variáveis. Durante o período do estudo, foram identificados 758023 focos de incêndio e 57269 hospitalizações. O índice de Moran foi significativo nos focos de incêndio, mas nas taxas de hospitalização, não houve autocorrelação espacial 
Antônio Carlos Pereira dos Santos Junior et al.

significativa, exceto em 2012. Os mapas temáticos e de núcleo mostram maiores ocorrências de incêndios no norte do estado, no chamado arco do desmatamento, e maiores taxas de hospitalizações na região sul do estado, possivelmente devido à ação dos ventos, deslocando poluentes gerados pelos incêndios no sul do estado.

Palavras-chave: ciências ambientais, desmatamento, poluentes atmosféricos, taxas de hospitalização.

\section{INTRODUCTION}

In 2008, cardiovascular diseases were responsible for 36 million deaths worldwide, being one of the leading causes of death, with low- and middle-income countries being the most affected. Brazil spends $75 \%$ of health costs on treating ischemic heart disease, according to World Bank data. (WHO, 2011).

In Brazil, in 2016 about 1.2 million hospitalizations were reported with more than 95 thousand deaths from circulatory system diseases; In the same year, in Mato Grosso state, about 15 thousand hospitalizations were reported, with 1500 deaths and a cost of $\mathrm{R} \$ 32$ million for cardiovascular diseases (Ministério da Saúde, 2019). Mortality rates were highest where there are the highest notifications of biomass burning, more specifically the state of Mato Grosso, which makes up the so-called deforestation arc, recording 332,473 burning notifications in 2016 (INPE, 2019).In addition to risk factors such as medical conditions, lifestyle and hereditary factors, several researchers have shown the relationship of air pollution with the emergence and /or complication of cardiovascular disease cases worldwide. (Gouveia, et al 2006, Nascimento et al 2012).

Exposure to air pollutants such as PM10, carbon monoxide (CO), ozone (O3), and others from burning biological materials and / or combustion from mobile or stationary sources have different effects on cardiovascular disease compared to respiratory disease, mostly affect adults and the elderly people, and cases are less relevant in relation to respiratory tract diseases whose effect is more intense. (Braga et al, 2001).

Spatial analysis of events is one of the ways to add value to geographic data by transforming it into productive information, thus facilitating decision-making and one of the areas that it has frequently used is public health (Carvalho, Souza-Santos, 2005). This approach, for example, allowed the identification of a spatial cluster in the middle Paraíba Valley in the State of Sao Paulo for hospitalizations due to acute myocardial infarction and ischemic heart disease (Soares and Nascimento, 2010), tuberculosis in children (Lorena et al., 2011), and pneumonia in children (Druk et al., 2004).

The aim of the present study was to identify spatial patterns of fire outbreaks and hospitalization rates for cardiovascular diseases in Mato Grosso, from the years 2012 to 2015.

\section{MATERIALS AND METHODS}

This is an exploratory and ecological study, providing information on the number of fire outbreaks and hospitalizations due to cardiovascular diseases reported in the state of Mato Grosso between 2012 and 2015.

The state of Mato Grosso is located in Central West Region of Brazil and comprises 141 municipalities distributed in an area of approximately 900 thousand $\mathrm{km}^{2}$, with a population of just over 3 million inhabitants. It lies between the parallels $9^{\circ}$ and $17^{\circ}$ South and longitude $50^{\circ}$ and $60^{\circ}$ West. It has a population density of 3.6 inhabitants. $\mathrm{km}^{-2}$. A state of continental dimensions, where much of its territory is occupied by the Legal Amazon. (Figure 1).

The data on fire outbreaks were provided by the Center for Weather Forecasting and Climate Studies (CPTEC) of the National Institute for Space Research (INPE) 
(https://prodwww-queimadas.dgi.inpe.br/bdqueimadas/). Hospitalization data were obtained from the Unified Health System Computer Department (Datasus) related to cardiovascular diseases referring to those belonging to the International Classification of Diseases, 10th revision (ICD 10) chapter IX, with diagnoses from I-00 to I-99 and according to place of residence in the state of Mato Grosso. Rates were created per 10,000 inhabitants with these data.

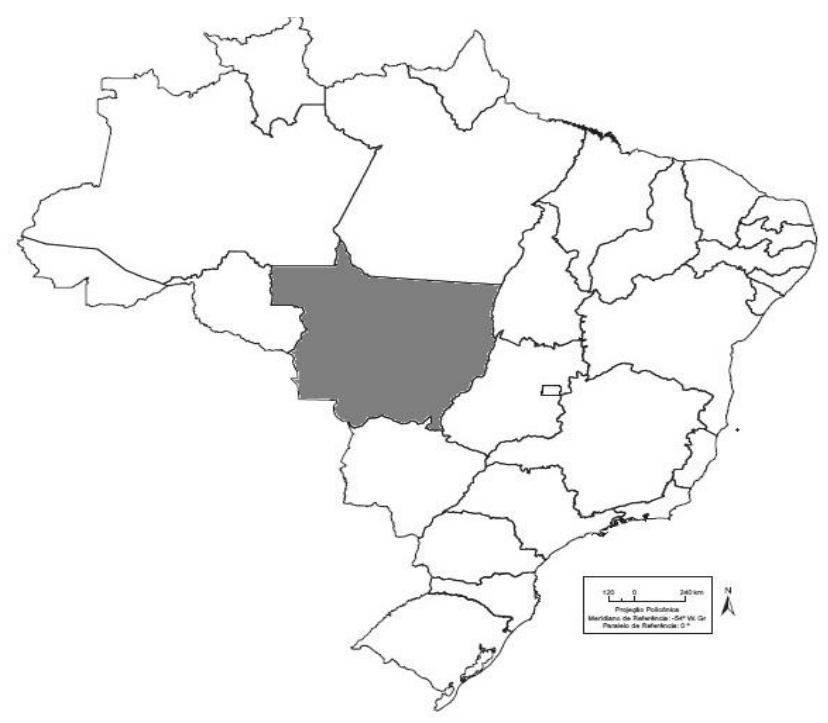

Figure 1. Geographical location of the state of Mato Grosso in Brazil.

Source: IBGE (2018).

The digital grid of the municipalities, utilized to perform the spatial analysis was obtained from the Brazilian Institute of Geography and Statistics (IBGE) (https://cidades.ibge.gov.br/). In this digital network, information on the number of fire outbreaks, hospitalizations and hospitalization rates per 10,000 inhabitants were inserted.

A correlation analysis of the influence of biomass burning on hospitalizations for cardiovascular diseases in the state of Mato Grosso was performed based on the collected data. Spatial analysis technique utilized TerraView 4.2.2 software, which is available from INPE (http://www.dpi.inpe.br/terraview/index.php). The data type used was of areas with counts and aggregated rates, subsequently generating thematic maps. The quantile stratification classification method was used. Analysis of absolute fire outbreak values and hospitalization rates was performed.

In order to perform the spatial statistical analysis, the Moran Global Index was chosen to estimate spatial correlation between burnt areas and the cardiovascular disease notification areas, therefore recognizing the circumstance of spatial dependence. The Moran Global I Index is the expression of autocorrelation, considering only the first neighbor (Druk et al., 2004) (Equation 1).

$$
I=\frac{\sum_{i=1}^{n} \sum_{j=1}^{n} w_{i j}\left(z_{i}-\bar{z}\right)\left(z_{j}-\bar{z}\right)}{\sum_{i=1}^{n}\left(z_{i}-\bar{z}\right)^{2}}
$$

In the above equation, $\mathrm{n}$ is the number of areas, $\mathrm{z}_{\mathrm{i}}$ and $\mathrm{z}_{\mathrm{j}}$ are the values of the attribute considered in area $i$ and $j$, wij are the elements of the normalized spatial proximity matrix and 
$\bar{Z}$ is the mean value of the attribute in the study region. In this case the correlation will be computed only for first order neighbors in space, as established by the wij weights.

Thus, the Moran Global index performs the test procedure, in which the null hypothesis is of spatial independence, whose value would be zero. Positive values (between 0 and +1 ) indicate, for direct correlation and negatives (between 0 and -1), inverse correlation. (Druk et al., 2004).

Another way to visualize the data is to use the kernel intensity estimator that produces a continuous surface and identifies regions with higher intensities, called hot spots. Thematic and kernel maps were constructed and the values of the Moran indices and respective p-values were estimated for the focal variables of fires and hospitalization rates for cardiovascular diseases.

As this is an ecological study with data available on the network, this project was not submitted to the Research Ethics Committee.

\section{RESULTS AND DISCUSSION}

From the year of 2012 to 2015,57269 hospitalizations for circulatory system diseases (Chapter IX of ICD-10) were reported in the state of Mato Grosso and 758023 fire outbreaks. Annual data of fire outbreaks, hospitalizations and average, minimum and maximum values and standard deviations of these variables are presented in Table 1.

Table 1. Mean values and respective standard deviations (sd), minimum (Min) and maximum (Max) values of the number of outbreaks and hospitalizations and the hospitalization rates per year, Mato Grosso 2012 - 2015.

\begin{tabular}{ccc}
\hline & Mean $(\mathrm{sd})$ & Min - Max \\
\hline Fire outbreaks & & \\
\hline 2012 & $1225.61679 .3)$ & $0-9064$ \\
2013 & $719.7(939.9)$ & $1-4863$ \\
2014 & $1187.01600 .1)$ & $3-7606$ \\
2015 & $2243.82698 .0)$ & $12-15298$ \\
\hline Hospital admissions & & $0-4276$ \\
\hline 2012 & $103.1(409.9)$ & $0-4469$ \\
2013 & $99.2(412.1)$ & $0-4989$ \\
2014 & $100.7(447.7)$ & $0-4974$ \\
2015 & $92.25(438.5)$ & $0-121.7$ \\
\hline Hospitality rates & & $0-134.5$ \\
\hline 2012 & $26.3(39.2)$ & $0-117.5$ \\
2013 & $23.0(30.7)$ & $0-119.8$ \\
\hline 2014 & $20.9(27.3)$ & \\
\hline
\end{tabular}

Among the cities of the state (Figure 2) and taking into account the largest number of outbreaks of burns, we highlight the municipalities of São Felix do Araguaia and Gaúcha do Norte that are repeated in the four years surveyed, besides Ribeirão Cascalheira, Paranatinga, Nova Ubiratã, Nova Maringá, Feliz Natal, Colniza and Cocalinho having the largest number of outbreaks in three of the four years surveyed, all of which make up the northern part of Mato Grosso, located in the deforestation arc. 
Regarding hospitalization rates, we have highlighted the municipalities of Torixoréu, Cáceres and Água Boa, which are repeated in the four years surveyed, that belong to the southern region of the state of Mato Grosso.

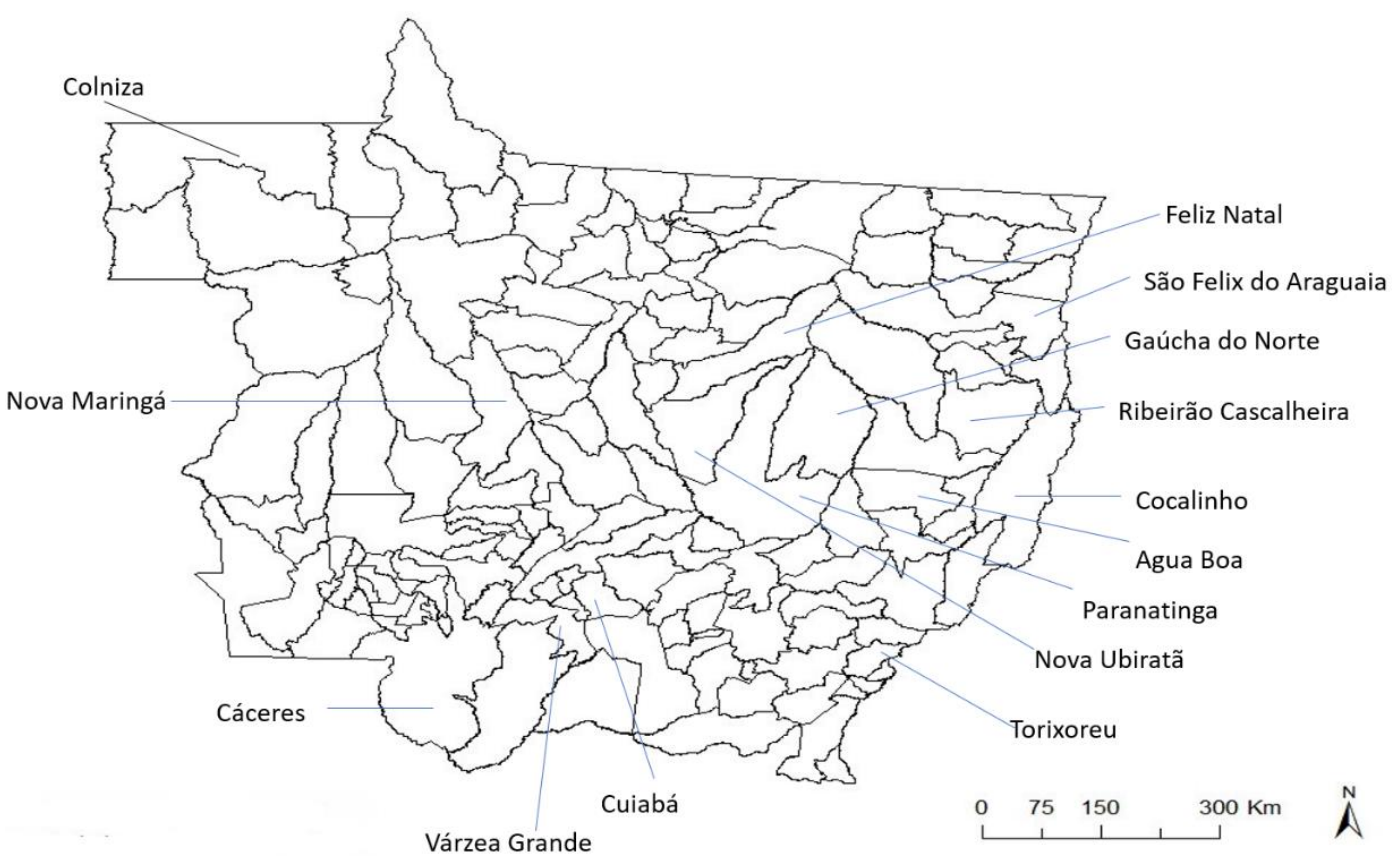

Figure 2. Municipalities with high burning rates in the state of Mato Grosso during the period studied.

The municipalities with high priority of intervention, due to the high rates of outbreaks of burns, which make up the so-called deforestation arc, are precisely those in the northern region of the state of Mato Grosso and those with low priority are concentrated in the southeast region.

Regarding the hospitalization rates for cardiovascular diseases, it was observed that between 2012 and 2015, in the State of Mato Grosso, except for 2012, all other years surveyed show that the regions with a high rate are relatively varied from 71.90 to 95.87 to very high, from 95.87 to 119.84 of reported cases.

The distribution of hospitalization rates due to cardiovascular diseases, and it can be noted that in all the years surveyed (2012 to 2015), the southern region of the state of Mato Grosso is the most affected, presenting higher hospitalization rates. (maps not shown)

Kernel maps were generated based on burn notifications and hospitalization rates. In Figure 3 of the years 2013 and 2015, it is evident that the highest densities of hospitalizations are in the southern part of the state of Mato Grosso whereas the highest densities of outbreaks occur in the northern part of the state.

The result of Moran Global (IM) (Table 2) indices range from 0.35 and 0.43 with p-value of 0.01, which represents, in view of this, a strong spatial autocorrelation. For hospitalization rates there was only significant spatial autocorrelation in the year 2012.

Given the data presented in this study, regarding the focus of burns and the hospitalization rates due to cardiovascular diseases, it is possible to observe that there is significant spatial autocorrelation for foci of burns that are located in the northern region of the state, but it was not possible to identify significant spatial autocorrelation. for CVD hospitalization rates, except in 2012, with the highest rates occurring in the southern part of the state, possibly because it is a more developed region and has better hospital care. 


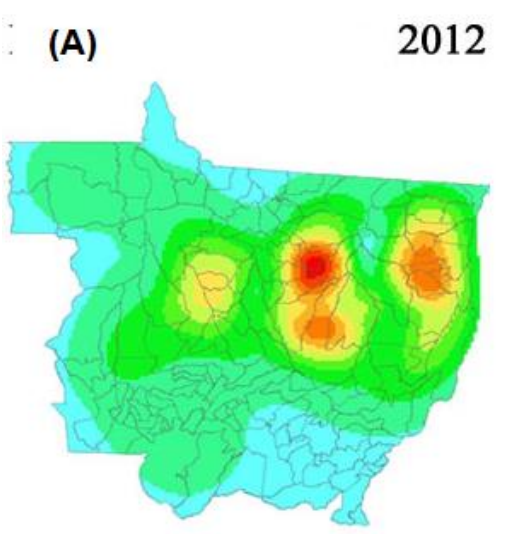

1 (E)

2012
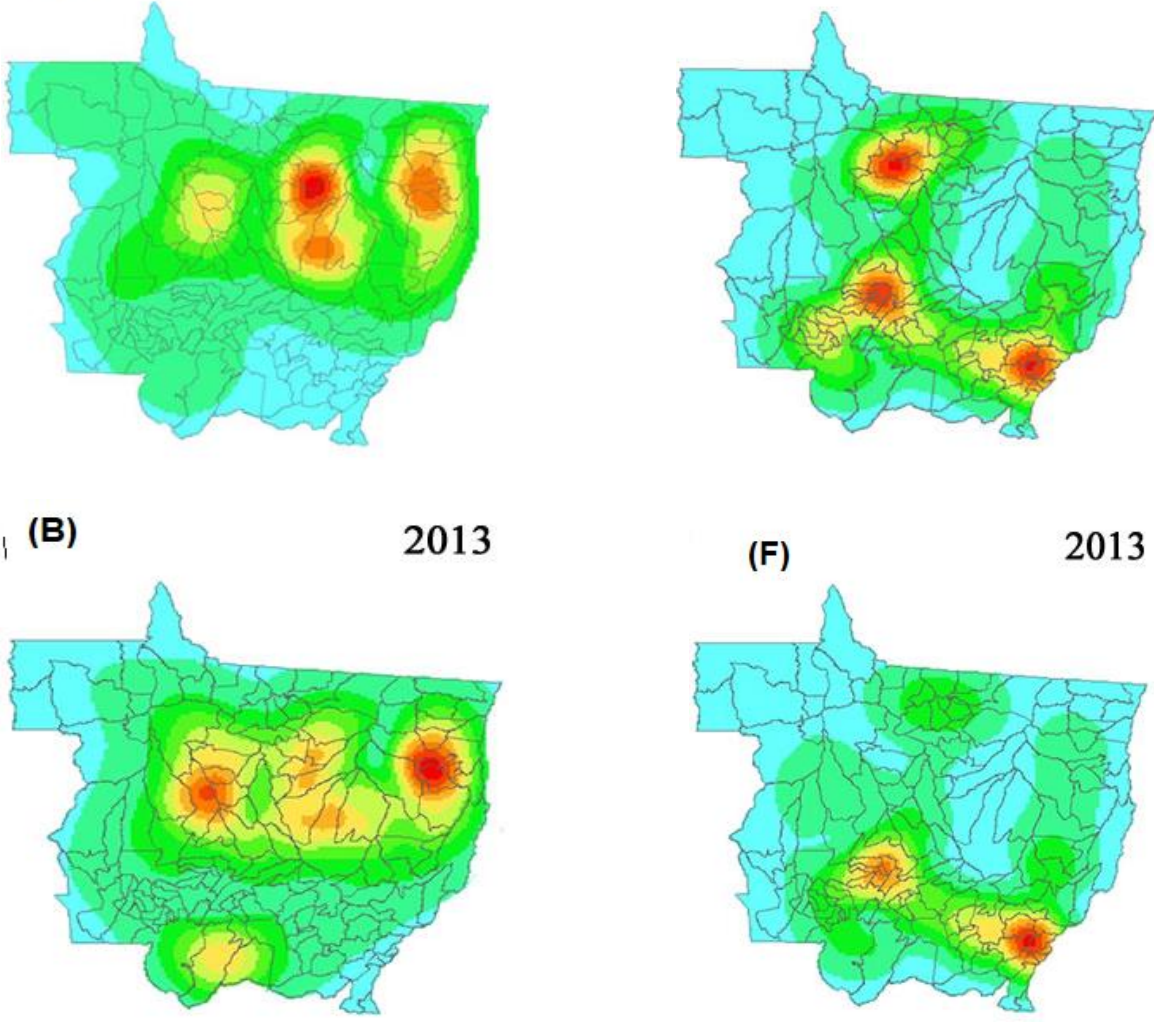

(C)

2014
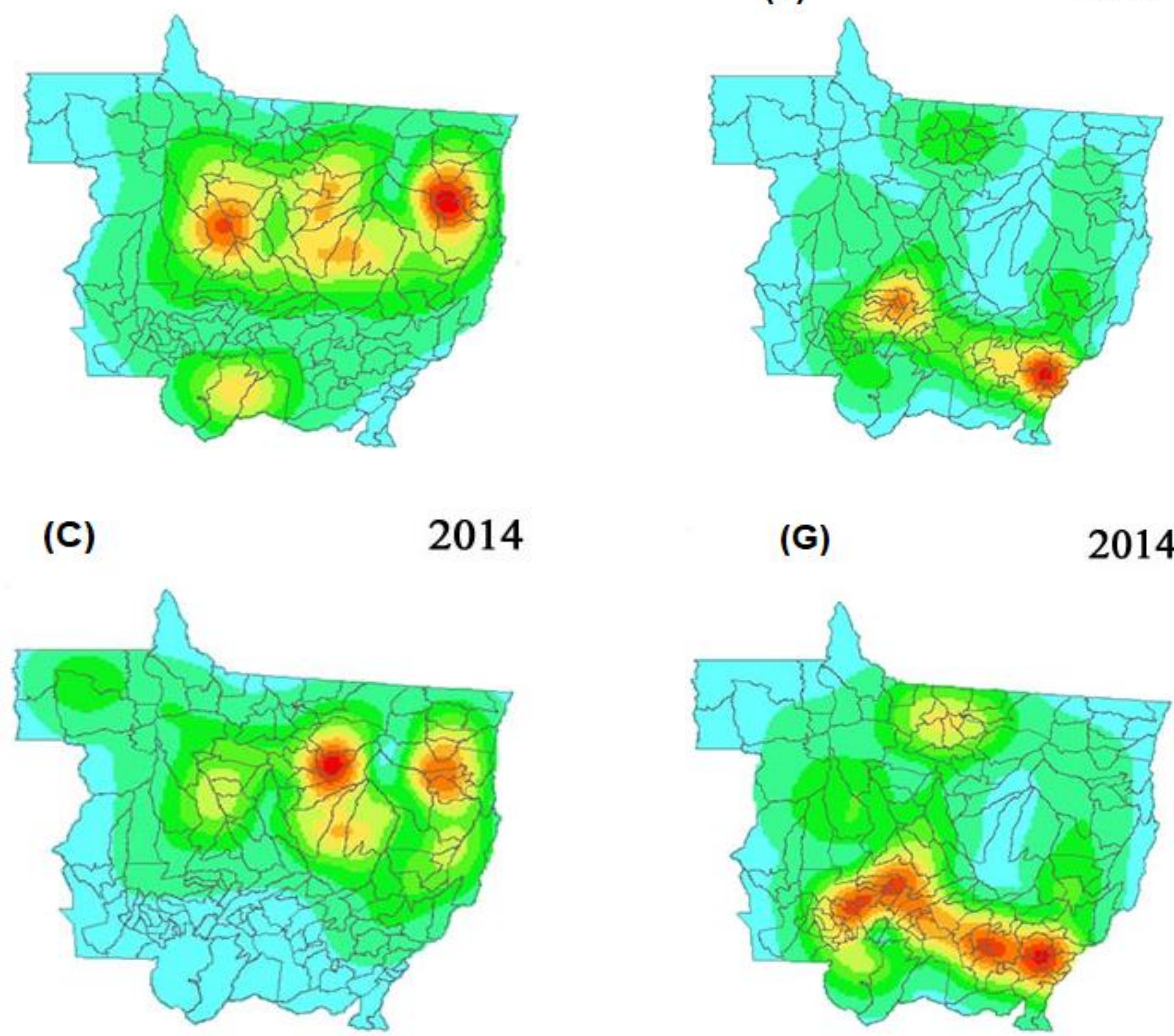

(G) 2014

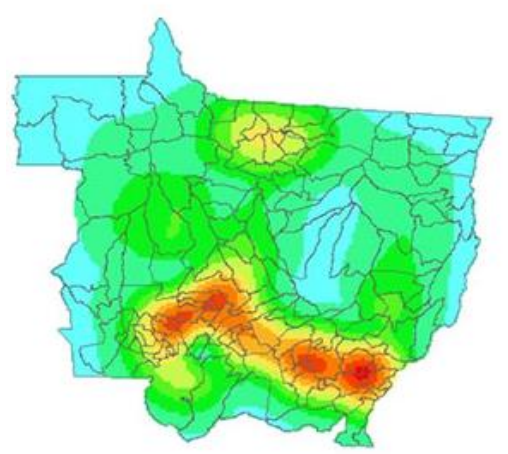

(D) 2015

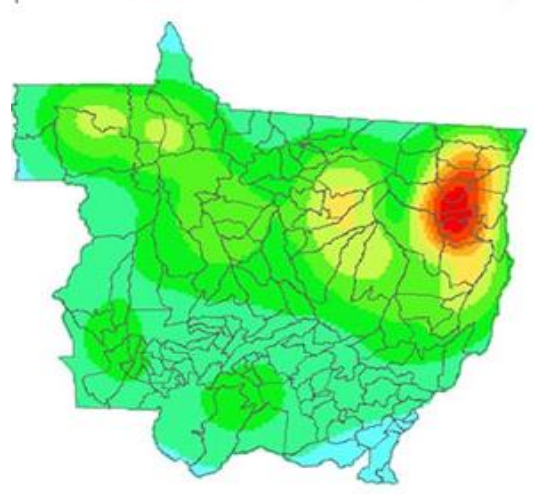

(H) 2015

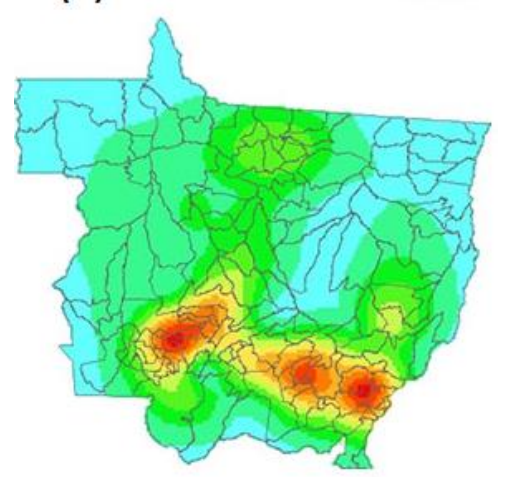

Figure 3. Kernel maps for burn outbreaks (A-D) and hospitalization rates (EH), Mato Grosso, Brazil, 2012-2015. 
Table 2. Moran Index (IM) values and respective p-values for the number of burn outbreaks and hospitalization rates for the years 2012 to 2015, Mato Grosso, 2012-2105.

\begin{tabular}{lcc}
\hline & $\mathrm{I}_{\mathrm{M}}$ & p-valor \\
\hline FIRES 2012 & 0.35 & 0.01 \\
FIRES 2013 & 0.35 & 0.01 \\
FIRES 2014 & 0.43 & 0.01 \\
FIRES 2015 & 0.39 & 0.01 \\
HOSPITALITY RATE 2012 & 0.06 & 0.04 \\
HOSPITALITY RATE 2013 & 0.00 & 0.53 \\
HOSPITALITY RATE 2014 & -0.05 & 0.20 \\
HOSPITALITY RATE 2015 & -0.04 & 0.14 \\
\hline
\end{tabular}

These data coincide with the results obtained by Andrade Filho et al. (2017) for Rondônia State, where they studied the spatial distribution of burns and mortality numbers in the elderly people. Moreover, the findings of the study presented here coincide with those described by Nascimento and Medeiros (2012) that forest fires are strongly related to human intervention that occur mainly by fires adopted by farmers as a way of cleaning crops. or the formation of pastures.

In the state of Mato Grosso, the causes of fire are mainly originated from the burning of biomass, that is, organic matter from the Amazon rainforest. And what contributes to natural fires are the rugged relief and dry soil, especially during the dry season, in addition to the hot weather that can trigger lightning conditions (Calderaro, 2002).

Studies on climatology may explain the reason for this occurrence, where the fires reach the northern part of Mato Grosso and the hospitalization rates are greater in the southern part of the state. Pollutants from biomass burning can be displaced by short and long distances by drafts, which can harm the health of people who live far from the source of pollution (Silva et al., 2013 and Paiva et al., 2014).

Fire outbreaks can be influenced by turbulent winds or advective, causing some pollutants to stay in the affected region (Silva et al., 2013). Soot circulates locally, influenced by turbulent winds or advection, and damages the health of nearby populations. In some cases, depending on the weather factor, high intensity fires may be influenced by convective winds, and consequently, enable the insertion of smoke in the low and medium troposphere (3 to $10 \mathrm{~km}$ high), developing a type of cloud called pirocumulus.

From the moment when pollutant-laden pirocumulus clouds reach the troposphere, transport to farther regions on a regional, continental and even global scale can be more efficient, influenced by air velocities. The dispersion of fire-related pollutants can influence the health of the elderly, as the gases and aerosols emitted by biomass burning can be transported over thousands of kilometers from the source areas, through the action of convective movements and displacement of air masses according to the circulation pattern (Freitas et al., 2005, Silva et al., 2013,).

While the kernel maps generated from the variables (fires and hospitalization rates) show concentration of fires in the northern part of the state, higher hospitalization rates are found in the southern part of the state.

Another similar fact, involving displacement of pollutants generated by biomass-burning, such as PM2.5 particulate matter, is that PM2.5 is related to cardiovascular disease mortality in Cuiabá and Várzea Grande. Its effects can be enhanced by high temperatures and low humidity during the dry season (Baars et al., 2011).

Previous studies have shown higher rates of hospitalization in regions located several kilometers away from major fire concentrations, thus suggesting that toxic products resulting from biomass burning may be carried by wind currents, which usually follow northwest- 
Antônio Carlos Pereira dos Santos Junior et al.

southeast direction, causing health issues to populations far from events (Andrade-Filho et al., 2017).

This study may have limitations, including possible errors in diagnosis of cardiovascular diseases as well as information on addresses of residence provided by the subjects. Another possible limitation lies in the fact that only hospitalization data by the Public Unified Health System are included, excluding private health service providers such as medical insurance and health operators. The use of satellites is also a limitation, since the spatial and temporal resolution characteristics of the sensors might overestimate or underestimate the number of fires foci. Lastly, a possible limitation is the lack of information on possible factors associated with cardiovascular diseases affecting individual cases, such as sedentary lifestyle, smoking, overweight and hypercholesterolemia.

\section{CONCLUSIONS}

Through the use of thematic maps, it was possible to verify that the northern region of Mato Grosso, which belongs to the so-called deforestation arc, is the most affected by the high proportion of burns and that the municipalities are spatially correlated and the municipalities with the highest hospitalization rates by CVD are in the southern region of the state and do not correlate spatially, except in 2012; In addition, this study confirms findings in other publications on the non-coincidence of fire outbreaks and CVD hospitalization rates.

\section{REFERENCES}

ANDRADE-FILHO, V. S.; ARTAXO-NETTO, P. E.; HACON, S. S.; CARMO, C. N. Distribuição espacial de queimadas e mortalidade em idosos em região da Amazônia Brasileira, 2001 - 2012. Ciênc. Saúde Coletiva. 2017.vol.22, n.1, pp.245-253. ISSN 1413-8123. http://dx.doi.org/10.1590/1413-81232017221.09622015

BAARS, H.; ANSMANN, A.; ALTHAUSEN, D.; ENGELMANN, R.; ARTAXO, P.; PAULIQUEVIS, T. Further evidence for significant smoke transport from Africa to Amazonia. Geophysical Research Letters. VOL. 38, L20802, 1-6 doi:10.1029/2011GL049200, 2011L208021of6

BRASIL. Ministério da Saúde. Departamento de Informática do SUS - DATASUS. Mortalidade hospitalar do SUS por local de internação - Brasil. Disponível em: http://tabnet.datasus.gov.br/cgi/tabcgi.exe?sih/cnv/niuf.def

BROOK, R. D.; RAJAGOPALAN, S.; POPE, C. A $3^{\text {rd }}$; BROOK, JR.; BHATNAGAR, A.; DIEZ-ROUX, AV. Particulate matter air pollution and cardiovascular disease: An update to the scientific statement from the American Heart Association. Circulation. 2010 Jun 1;121(21):2331-78. doi: 10.1161/CIR.0b013e3181dbece1

CALDARARO, N. Human ecological intervention and the role of forest fires in human ecology. Science of the Total Environment.292(3):141-65 • July 2002.

CARVALHO, M. S.; SOUZA-SANTOS, R. Analysis of spatial data in public health: methods, problems, and perspectives. Cad. Saúde Publica. 2005.Cad. Saúde Pública, Rio de Janeiro, 21(2):361-378, mar-abr, 2005. http://dx.doi.org/10.1590/S0102311X2005000200003

DRUCK, S.; CARVALHO, M. S.; CÂMARA, G.; MONTEIRO, A. V. M. Análise espacial de dados geográficos. EMBRAPA. 2004. Disponível em: http://www.dpi.inpe.br/gilberto/livro/analise/ 
FREITAS, S. R.; LONGO, K. M.; DIAS, M. A. F. S.; DIAS P. L. S. Emissões de queimadas em ecossistemas da América do Sul. Estud. av. 2005, v.19, n. 53, pp.167-185.

FREITAS, S. R.; LONGO, K. M.; SILVA DIAS, M. A. F.; SILVA DIAS, PL.; CHATFIELD, R.; PRINS, E. Monitoring the transport of biomass burning emissions in South America. Environmental Fluid Mechanics. 2005.5 (1-2), 135-167.

GOUVEIA, N.; FREITAS, C. U.; Martins, L. C.; MARCILIO, I. O. Hospitalizações por causas respiratórias e cardiovasculares associadas à contaminação atmosférica no Município de São Paulo, Brasil. Cad. Saúde Pública. 2006. 22(12):2669-77. https://doi.org/10.1590/S0102-311X2006001200016

INSTITUTO BRASILEIRO DE GEOGRAFIA E ESTATISTICA. Atlas Escolar Brasil Físico. Avalable: https://atlasescolar.ibge.gov.br/images/atlas/mapas_brasil/brasil_ fisico.pdf (cited 02.01.2018).

INSTITUTO NACIONAL DE PESQUISAS ESPACIAIS. Divisão de Processamento de Imagens. INPE - Programa Queimadas. Disponível em https://prodwwwqueimadas.dgi.inpe.br/bdqueimadas

LANGRISH, J. P.; BOSSON, J.; UNOSSON, J.; MUALA, A.; NEWBY, D. C.; MILLS, N. L. Cardiovascular effects of particulate air pollution exposure: time course and underlyingmechanisms. Journal of Internal Medicine. 2012. Sep;272(3):224-39. doi: $10.1111 / \mathrm{j} .1365-2796.2012 .02566$

LIU, L.; RUDDY, T.; DALIPAJ, M.;POON, R.; SZYSZKOWICZ, M.; YOU, H. Effects of indoor, outdoor, and personal exposure to particulate air pollution on cardiovascular physiology and systemic mediators in seniors. J. Occup. Environ Med. 51(9):10881098, SEPTEMBER 2009. DOI: 10.1097/JOM.0b013e3181b35144

LORENA, R. B.; BERGAMASCHI, R. B.; LEITE, G. R. Análise Exploratória Espacial do Índice de Desenvolvimento Humano Municipal do Estado do Espírito Santo. Anais. XV Simpósio Brasileiro de Sensoriamento Remoto - SBSR, Curitiba, PR, Brasil, 30 de abril a 05 de maio de 2011, INPE p.4776.

NASCIMENTO, L. F. C. Air pollution and cardiovascular hospital admissions in a mediumsized city in São Paulo State, Brazil. Brazilian Journal of Medical and Biological Research. [online]. 2011, vol. 44, n.7, pp.720-724. Epub June 21, 2011 ISSN 1414431X. http://dx.doi.org/10.1590/S0100-879X2011007500079

NASCIMENTO, L. F. C.; FRANCISCO, J. B.; PATTO, M. B. R.; ANTUNES, AM. Environmental pollutants and stroke-related hospital admissions. Cad. Saúde Pública. . vol.28 no.7 Rio de Janeiro July 2012. http://dx.doi.org/10.1590/S0102$311 X 2012000700010$

NASCIMENTO, L. F. C.; MEDEIROS, A. P. P. Internações por pneumonias e queimadas: uma abordagem espacial. J. Pediatr. 2012.88:177-83.

OLIVEIRA, B. F. A.; IGNOTTI, E.; HACON, S. S. A systematic review of the physical and chemical characteristics of pollutants from biomass burning and combustion of fossil fuels and health effects in Brazil. Cad. Saúde Pública. 2011.27 (9), 1678-1698.

PAIVA, S. L. P.; NEVES, S. M. A. S.; MUNIZ, C. C.; NEVES, R. J. Análise de ocorrência de queimadas em unidades geomorfológicas na bacia amazônica, contida na região sudoeste mato-grossense. Revista Bionorte. 2014.V.10, n.1, p. 95-100, 2014. Available in: 
<http://www.periodicos.ufam.edu.br/revistageonorte/article/view/1660>. Accessed in: 01 fev. 2017.

RODRIGUES, P. C. O.; PINHEIRO, S. L.; JUNGER, W.; IGNOTTI, E; HACON, S. S. Climatic variability and morbidity and mortality associated with particulate matter. Rev. Saúde Pública. 2017. 51:91 https://doi.org/10.11606/S1518-8787.2017051006952

SILVA, A. M.; MATTOS, I. E.; IGNOTTI, E.; HACON, S. S. Material particulado originário de queimadas e doenças respiratórias. Rev. Saúde Pública. 2013.47 (2) Jun 2013 https://doi.org/10.1590/S0034-8910.2013047004410

SOARES, P. A.; NASCIMENTO, L. F. C. Análise espacial das internações por doenças do coração no Vale do Paraíba. Arq. Bras. Cardiol. 2010. vol.94 no.6 São Paulo June 2010. http://dx.doi.org/10.1590/S0066-782X2010005000038

WORLD HEALTH ORGANIZATION. Global status report on non communicable diseases 2010. Geneva, 2011. 176p. 176p. 176p. 